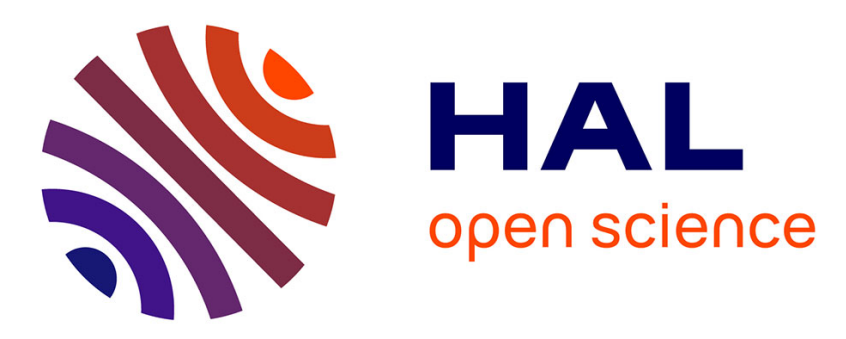

\title{
Mechanochemical synthesis of new coordination polymers with acetylenedicarboxylate as bridging ligand
}

Uwe Ruschewitz, Irena Stein

\section{To cite this version:}

Uwe Ruschewitz, Irena Stein. Mechanochemical synthesis of new coordination polymers with acetylenedicarboxylate as bridging ligand. Journal of Inorganic and General Chemistry / Zeitschrift für anorganische und allgemeine Chemie, 2009, 636 (2), pp.400. 10.1002/zaac.200900368 . hal-00530823

\section{HAL Id: hal-00530823 \\ https://hal.science/hal-00530823}

Submitted on 30 Oct 2010

HAL is a multi-disciplinary open access archive for the deposit and dissemination of scientific research documents, whether they are published or not. The documents may come from teaching and research institutions in France or abroad, or from public or private research centers.
L'archive ouverte pluridisciplinaire HAL, est destinée au dépôt et à la diffusion de documents scientifiques de niveau recherche, publiés ou non, émanant des établissements d'enseignement et de recherche français ou étrangers, des laboratoires publics ou privés. 


\section{Mechanochemical synthesis of new coordination polymers with acetylenedicarboxylate as bridging ligand}

\begin{tabular}{|r|l|}
\hline Journal: & Zeitschrift für Anorganische und Allgemeine Chemie \\
\hline Manuscript ID: & zaac. 200900368.R1 \\
\hline Wiley - Manuscript type: & Article \\
\hline Date Submitted by the \\
Author: & 23-Sep-2009 \\
\hline Complete List of Authors: & $\begin{array}{l}\text { Ruschewitz, Uwe; Universität zu Köln, Department of Chemistry } \\
\text { Stein, Irena; Universität zu Köln, Department of Chemistry }\end{array}$ \\
\hline Keywords: & $\begin{array}{l}\text { Alkaline Earth Metal, Coordination Polymer, Crystal Structure, } \\
\text { Mechanochemical Synthesis, X-ray Powder Diffraction }\end{array}$ \\
\hline
\end{tabular}

\section{S) ScholaroNE" \\ Manuscript Central}


Mechanochemical synthesis of new coordination polymers with acetylenedicarboxylate as bridging ligand Irena Stein and Uwe Ruschewitz ${ }^{*}$

Köln, Institut für Anorganische Chemie der Universität

Dedicated to Prof. Hans-Jörg Deiseroth on the occasion of his $65^{\text {th }}$ birthday.

Bei der Redaktion eingegangen am 


\begin{abstract}
CaADC}$ (1) and $\mathrm{Mg}(\mathrm{ADC})\left(\mathrm{H}_{2} \mathrm{O}\right)_{2}$ (2) were synthesized by grinding $\mathrm{Ca}\left(\mathrm{CH}_{3} \mathrm{COO}\right)_{2}$ and $\mathrm{Mg}\left(\mathrm{CH}_{3} \mathrm{COO}\right)_{2} \cdot 4 \mathrm{H}_{2} \mathrm{O}$ with acetylenedicarboxylic acid $\left(\mathrm{H}_{2} \mathrm{ADC}\right)$ in an agate mortar. After careful heating for two hours in an argon atmosphere at moderate temperatures $-50^{\circ} \mathrm{C}$ and $70^{\circ} \mathrm{C}$, resp. - polycrystalline materials of good crystallinity were obtained. The crystal structures of $\mathbf{1}$ and $\mathbf{2}$ were solved and refined from X-ray powder diffraction data. In the course of the structural refinement it turned out that $\mathbf{1}$ and $\mathbf{2}$ are isotypic to $\operatorname{SrADC}\left(\mathrm{I} 4_{1} / \mathrm{amd}, \mathrm{Z}=4\right)$ and $\mathrm{Mn}(\mathrm{ADC})\left(\mathrm{H}_{2} \mathrm{O}\right)_{2}(\mathrm{I} 2 / \mathrm{a}, Z=4)$. In both compounds metal cations are connected by bridging $\mathrm{ADC}^{2-}$ ligands to form a $3 \mathrm{D}$ coordination network. Thermoanalytical investigations show that CaADC decomposes above $50^{\circ} \mathrm{C}$, whereas for $\operatorname{Mg}(\mathrm{ADC})\left(\mathrm{H}_{2} \mathrm{O}\right)_{2}$ a mass loss of approx. $33 \%$ is observed above $150^{\circ} \mathrm{C}$. The loss of one water molecule as well as a decarboxylation is very likely. The remaining residue is amorphous to X-rays.
\end{abstract}

\title{
Mechanochemische Synthese von neuen Koordinationspolymeren mit Acetylendicarboxylat als verbrückendem Liganden
}

Inhaltsübersicht Durch Verreiben von $\mathrm{Ca}\left(\mathrm{CH}_{3} \mathrm{COO}\right)_{2}$ bzw. $\mathrm{Mg}\left(\mathrm{CH}_{3} \mathrm{COO}\right)_{2} \cdot 4 \mathrm{H}_{2} \mathrm{O}$ mit Acetylendicarbonsäure $\left(\mathrm{H}_{2} \mathrm{ADC}\right)$ in einem Achatmörser wurden CaADC (1) und $\mathrm{Mg}(\mathrm{ADC})\left(\mathrm{H}_{2} \mathrm{O}\right)_{2}$ (2) dargestellt. Nach Heizen bei $50^{\circ} \mathrm{C}$ bzw. $70^{\circ} \mathrm{C}$ für zwei Stunden in einer Argon-Atmosphäre konnte ein polykristallines Pulver guter Kristallinität erhalten werden. Die Kristallstrukturen von $\mathbf{1}$ und $\mathbf{2}$ wurden gelöst und verfeinert auf Basis von Röntgenpulverbeugungsdaten. Im Laufe der Strukturverfeinerung stellte sich heraus, dass beide Verbindungen isotyp $\mathrm{zu}$ bereits bekannten Koordinationspolymeren des Acetylendicarboxylats sind: $\operatorname{SrADC}\left(\mathrm{I}_{1} / \mathrm{amd}, Z=4\right)$ bzw. $\mathrm{Mn}(\mathrm{ADC})\left(\mathrm{H}_{2} \mathrm{O}\right)_{2}(\mathrm{I} 2 / \mathrm{a}, Z=4)$. In

beiden Verbindungen werden die Metallkationen über verbrückende $\mathrm{ADC}^{2-}$ - Liganden $\mathrm{zu}$ einem 3D-Koordinationsnetzwerk verknüpft. Thermoanalytische Untersuchungen zeigen, dass sich $\mathrm{CaADC}$ oberhalb $50^{\circ} \mathrm{C}$ kontinuierlich zersetzt, während für $\operatorname{Mg}(\mathrm{ADC})\left(\mathrm{H}_{2} \mathrm{O}\right)_{2}$ oberhalb $150^{\circ} \mathrm{C}$ ein Massenverlust von ca. $33 \%$ gefunden wird. Dieser deutet auf den Verlust eines Wassermoleküls sowie eine Decarboxylierung hin. Der zurückbleibende Rückstand ist röntgenamorph.

Keywords: Alkaline Earth Metal; Coordination Polymer; Crystal Structure;

Mechanochemical Synthesis; X-ray Powder Diffraction 
${ }^{*}$ Prof. Dr. Uwe Ruschewitz
Department für Chemie der Universität zu Köln

Greinstraße 6

50939 Köln

Germany

Fax: (+49)-(0)221-470-4899

Email: Uwe.Ruschewitz@uni-koeln.de 


\section{Introduction}

In the last years the synthesis and structural characterisation of coordination polymers has been in the focus of many research groups world-wide. This interest is based on the easy preparative accessibility of these compounds and their potential applications [1]. The latter are mainly concentrated on porous coordination polymers (PCP) or metal-organic frameworks (MOF) [2]. But also non-porous coordination polymers promise interesting properties [3]. In the last years we have mainly concentrated our work in this field on the synthesis of coordination polymers containing acetylenedicarboxylate $\left(\mathrm{ADC}^{2-}\right)$ as bridging ligand [4-15]. Anhydrous [4-6] as well as water containing compounds [7-12] were synthesized. Recently, we were able to incorporate additional ligands like $\mathrm{NO}_{3}{ }^{-}[13]$ or $\mathrm{N}$ donor ligands $[14,15]$ in these coordination polymers.

Most coordination polymers described in the literature were synthesized by solvothermal methods. Especially for porous compounds like MOF-5 [16], MIL-53 [17] or HKUST-1 [18] it is the method of choice. However, for the synthesis of coordination polymers containing $\mathrm{ADC}^{2-}$ as bridging ligand solvothermal methods are not applicable, as $\mathrm{ADC}^{2-}$ decomposes under the conditions typically used in solvothermal syntheses. Therefore other synthesis routes like slow evaporation of the solvent, diffusion methods in an $\mathrm{H}$ shaped tube or gel methods were successfully applied. Recently, it was shown that mechanochemical syntheses can be used to synthesize a variety of interesting solid state compounds [19]. Among them are carbides [20] as well as coordination polymers [21-23]. It was already shown that known acetylenedicarboxylates can be reproduced by mechanochemical methods [23]. But to our knowledge, the synthesis and structural characterisation of new and unknown coordination polymers obtained via mechanochemical routes is very rare. Here we present two new coordination polymers containing $\mathrm{ADC}^{2-}$ as bridging ligand, which were synthesized by mechanochemical methods and whose crystal structures were solved and refined from X-ray powder diffraction data.

\section{Synthesis}

Polycrystalline powders of $\mathbf{1}$ and $\mathbf{2}$ were obtained by grinding acetates of the respective alkaline earth metals with acetylenedicarboxylic acid $\left(\mathrm{H}_{2} \mathrm{ADC}\right)$ in an agate mortar. To 


\section{Crystal Structures}

Polycrystalline powders of reasonable crystallinity (see Figure 1) were obtained by mechanochemical synthesis and subsequent heating at very modest temperatures as described above. Samples were sealed in glass capillaries $(\varnothing 0.3 \mathrm{~mm})$ in an argon atmosphere. Powder diffraction data were collected on a Stoe STADI P X-ray powder diffractometer $(T \approx 295 \mathrm{~K}$, $\mathrm{CuK} \alpha_{1}$ radiation, Ge monochromator, linear PSD detector). The collection time for one data set was approx. 48 hours with steps $\Delta 2 \theta=0.01^{\circ}$. More details of the measurements are given in Table 1.

\section{$<$ Table $1>$}

$<$ Figure $1>$ 
The diffraction data were analysed using the WinXPOW software package [24]. The diffraction data of CaADC (1) were indexed in a tetragonal unit cell $(\mathrm{a} \approx 688 \mathrm{pm}, \mathrm{c} \approx 1020$ pm) using TREOR [25]. The reflection conditions led to I4 $4_{1} /$ amd (no. 141) as possible space group. At this point it was already speculated that CaADC is isotypic to $\operatorname{SrADC}\left(\mathrm{I}_{1} / \mathrm{amd}, \mathrm{a} \approx\right.$ $721 \mathrm{pm}, \mathrm{c} \approx 1034 \mathrm{pm}$ ) [4]. A comparison of the diffraction data of 1 with those of SrADC confirmed this assumption. Using the atomic parameters of SrADC as starting parameters the diffraction data of 1 were successfully refined using GSAS [26]. Bond soft constraints were used within the $\mathrm{ADC}^{2-}$ anion $(\mathrm{C} 1-\mathrm{C} 1: 120 \mathrm{pm}, \mathrm{C} 1-\mathrm{C} 2: 147 \mathrm{pm}, \mathrm{C} 2-\mathrm{O}: 125 \mathrm{pm})$. More details of the structural refinement are given in Table 1 [27]. Selected interatomic distances and bond angles are listed in Table 2.

$<$ Table $2>$

As already mentioned, CaADC (1) crystallizes in the SrADC type structure [4]. The carbon backbone of the $\mathrm{ADC}^{2-}$ dianion is aligned along the $c$ axis of the tetragonal unit cell with the two carboxylate groups being perpendicular to each other (point group $\overline{4} 2 \mathrm{~m}$ ). The bond distances within the anion are constrained, but the resulting bond angles are as expected (see Table 2). Each $\mathrm{Ca}^{2+}$ cation is surrounded by eight oxygen atoms of six different carboxylate ligands (Figure 2) with two of them coordinating in a chelating-type bidentate mode (Ca-O: $272.8 \mathrm{pm}, 4 \mathrm{x})$ and four in a unidentate mode (Ca-O: $231.56 \mathrm{pm}, 4 \mathrm{x})$. Each oxygen atom of the carboxylate groups is involved in both a bidentate and a unidentate coordination and bridges two calcium atoms in a way that a three dimensional framework results.

$<$ Figure $2>$

The $\mathrm{Ca}^{2+}$ cations display an almost undistorted diamond-like arrangement, as can be seen in Figure 3. Each $\mathrm{Ca}^{2+}$ is surrounded by four other metal ions $(428.1 \mathrm{pm}, 4 \mathrm{x})$, the resulting tetrahedron is only slightly distorted $\left(\mathrm{Ca}-\mathrm{Ca}-\mathrm{Ca}: 106.9^{\circ}, 2 \mathrm{x}\right.$ and $\left.110.8^{\circ}, 4 \mathrm{x}\right)$. This close relationship to the diamond structure is also reflected in the unit cell $(c \approx \sqrt{2} \cdot a)$ and space group of $\mathbf{1}$, as $\mathrm{I}_{1} / \mathrm{amd}$ is a direct subgroup of $\mathrm{Fd} \overline{3} \mathrm{~m}$, the space group of the diamond structure.

$<$ Figure $3>$

The diffraction data of $\mathrm{Mg}(\mathrm{ADC})\left(\mathrm{H}_{2} \mathrm{O}\right)_{2}$ (2) were indexed in a monoclinic unit cell using ITO [28]. The reflection conditions led to Ia (no. 9) and I2/a (no. 15) as possible space groups. The crystal structure of 2 was solved in space group I2/a using EXPO2004 [29]. Only after structural solution it became clear that $\mathbf{2}$ is isotypic to known compounds of composition 
$\mathrm{M}^{\mathrm{II}}(\mathrm{ADC})\left(\mathrm{H}_{2} \mathrm{O}\right)_{2}$ with $\mathrm{M}^{\mathrm{II}}=\mathrm{Mn}$ [30], $\mathrm{Co}$ [7], $\mathrm{Ni}$ [9]. The latter were described in $\mathrm{C} 2 / \mathrm{c}$. As the monoclinic angle $\beta$ is larger than $120^{\circ}$ using this cell choice, it was abandoned to transform the structural data of 2 from I2/a to C2/c. The structural refinement was performed with GSAS [26]. Bond soft constraints (C1 - C1: 120 pm, C1 - C2: 147 pm, C2 - O: 125 pm) and bond angle soft constraints $\left(\mathrm{O} 1-\mathrm{C} 2-\mathrm{O} 2: 124^{\circ}, \mathrm{O} 1-\mathrm{C} 2-\mathrm{C} 1: 118^{\circ}, \mathrm{O} 2-\mathrm{C} 2-\mathrm{C} 1: 118^{\circ}\right)$ were applied within the $\mathrm{ADC}^{2-}$ anion. More details of the structural refinement are given in Table 1 [27]. Selected interatomic distances and bond angles are listed in Table 2.

$$
<\text { Figure } 4>
$$

As already mentioned $\mathrm{Mg}(\mathrm{ADC})\left(\mathrm{H}_{2} \mathrm{O}\right)_{2}$ (2) crystallizes in the $\mathrm{Mn}(\mathrm{ADC})\left(\mathrm{H}_{2} \mathrm{O}\right)_{2}$ type structure [30]. The coordination sphere around a $\mathrm{Mg}^{2+}$ cation is shown in Figure $4 . \mathrm{Mg}^{2+}$ is coordinated octahedrally by six oxygen atoms stemming from four different carboxylate ligands $(\mathrm{Mg}-\mathrm{O}$ : $205.2 \mathrm{pm}, 2 \mathrm{x} ; 217.1 \mathrm{pm}, 2 \mathrm{x})$ and two water molecules (Mg - O: 213.8 pm, 2x). Each oxygen atom of the carboxylate groups is coordinated in a unidentate mode to just one $\mathrm{Mg}^{2+}$ cation. These cations are connected by the ligands to form a three dimensional framework. This is shown in a projection along [010] in Figure 5. The carboxylate groups of the $\mathrm{ADC}^{2-}$ ligand are almost perpendicular to each other. The angle between the planes formed by the carboxylate groups is $98.14^{\circ}$.

\section{$<$ Figure $5>$}

\section{Thermoanalytical Investigations}

To check the thermal stability of $\mathrm{CaADC}$ (1) and $\mathrm{Mg}(\mathrm{ADC})\left(\mathrm{H}_{2} \mathrm{O}\right)_{2}$ (2), DTA/TG investigations were performed on both compounds in the temperature range $20^{\circ} \mathrm{C}-300^{\circ} \mathrm{C}$ with a heating rate of $5^{\circ} \mathrm{C} / \mathrm{min}$ in an inert argon atmosphere (Netzsch STA $409 \mathrm{C} / \mathrm{CD}, \mathrm{Al}_{2} \mathrm{O}_{3}$ container). The results on CaADC are shown in Figure 6. It is obvious that $\mathbf{1}$ decomposes at very modest temperatures starting at approx. $50^{\circ} \mathrm{C}$, the temperature at which the sample was heated to improve its crystallinity. The decomposition occurs continuously as indicated by a permanent mass loss. A very broad signal in the DTA curve at approx. $150^{\circ} \mathrm{C}$ cannot be interpreted. The low thermal stability of CaADC compared to isotypic SrADC, which decomposes above $700 \mathrm{~K}$ [4], is surprising, but no reasonable explanation can be given at the moment. 
The DTA/TG curve obtained for $\mathrm{Mg}(\mathrm{ADC})\left(\mathrm{H}_{2} \mathrm{O}\right)_{2}(2)$ is shown in Figure 7. Above $150^{\circ} \mathrm{C} \mathrm{a}$ mass loss of approx. $33 \%(\approx 57 \mathrm{~g} / \mathrm{mol})$ accompanied by a broad endothermic DTA signal followed by a sharper exothermic signal is observed. This could be indicative for a loss of one water molecule $(18 \mathrm{~g} / \mathrm{mol})$ followed by a decarboxylation $(44 \mathrm{~g} / \mathrm{mol})$. But also the loss of two water molecules (36 g/mol) followed by the release of one $\mathrm{CO}$ molecule $(28 \mathrm{~g} / \mathrm{mol})$, as found for SrADC [4], cannot be excluded at this point. The residue obtained after this thermal treatment is amorphous to $\mathrm{X}$-rays so that no further information was available.

$$
<\text { Figure } 7>
$$

\section{Conclusion and Outlook}

Two new coordination polymers were synthesized by mechanochemical synthesis involving grinding of the starting materials in an agate mortar. After heating at moderate temperatures crystalline samples were obtained giving X-ray powder diffraction patterns of reasonable quality (Figure 1). Although both compounds are isotypic to known compounds, the crystal structure of 2 was solved $a b$ initio, as the isotypy to $\mathrm{Mn}(\mathrm{ADC})\left(\mathrm{H}_{2} \mathrm{O}\right)_{2}$ [30] was only recognized after the structural solution. This shows that compounds obtained by mechanochemical synthesis cannot only be characterized by comparison with known compounds, but also an ab initio structural solution of unknown compounds is possible. It was also attempted to solve the crystal structure of $\mathbf{1}$ ab initio from powder diffraction data, although the isotypy to SrADC [4] was obvious. Using EXPO2004 [29] a reasonable structural model was obtained in space group $\mathrm{I}_{1} / \mathrm{a}$. After transformation into space group I $4_{1} /$ amd a structural model very similar to the final crystal structure as given in Table 1 and Figure 2 was obtained.

Especially the synthesis of CaADC (1) was of interest for us, as SrADC [4] and BaADC [31] show a negative thermal expansion. As $\mathbf{1}$ is isotypic to the two other alkaline earth metal compounds, it can be expected that negative thermal expansion also occurs in 1 . Due to the low thermal stability of $\mathbf{1}$, temperature dependent measurements below room temperature are necessary, which will be recorded in the near future.

Many coordination polymers and MOFs are synthesized by solvothermal methods. But this approach is not applicable for the synthesis of coordination polymers containing acetylenedicarboxylate as linking ligand, as it decomposes under the conditions of a 


\section{Acknowledgements}

We would like to thank Dr. Klaus Müller-Buschbaum and Peter Kliesen for the DTA/TG investigations. 


\section{References}

[1] U. Mueller, M. Schubert, F. Teich, H. Puetter, K. Schierle-Arndt, J. Pastré, J. Mater. Chem. 2006, 16, 626.

[2] A few recent reviews in this field: a) R. A. Fischer, C. Wöll, Angew. Chem. 2008, 120, 8285; Angew. Chem. Int. Ed. 2008, 47, 8164; b) G. Férey, Chem. Soc. Rev. 2008, 37, 191; c) S. Kitagawa, R. Matsuda, Coord. Chem. Rev. 2007, 251, 2490.

[3] A. K. Cheetham, C. N. R. Rao, Science 2007, 318, 58.

[4] F. Hohn, I. Pantenburg, U. Ruschewitz, Chem. Eur. J. 2002, 8, 4536-4541.

[5] I. Stein, C. Näther, U. Ruschewitz, Solid State Sci. 2006, 8, 353-358.

[6] R. Ahlers, U. Ruschewitz, Solid State Sci. 2009, 11, 1058-1064.

[7] I. Pantenburg, U. Ruschewitz, Z. Anorg. Allg. Chem. 2002 , 628, 1697-1702.

[8] U. Ruschewitz, I. Pantenburg, Acta Crystallogr. 2002, C58, m483-m484.

[9] F. Hohn, H. Billetter, I. Pantenburg, U. Ruschewitz, Z. Naturforsch. 2002, 57 b, 13751381 .

[10] H. Billetter, F. Hohn, I. Pantenburg, U. Ruschewitz, Acta Crystallogr. 2003, C59, m130-m131.

[11] H. Billetter, I. Pantenburg, U. Ruschewitz, Z. Naturforsch. 2004, 59 b, 903-909.

[12] I. Stein, U. Ruschewitz, Acta Crystallogr. 2005, E61, m2680-m2682.

[13] A. Schuy, H. Billetter, F. Hohn, I. Pantenburg, U. Ruschewitz, Z. Kristallogr. 2005, $220,250-258$.

[14] I. Stein, M. Speldrich, H. Schilder, H. Lueken, U. Ruschewitz, Z. Anorg. Allg. Chem. 2007, 633, 1382-1390.

[15] I. Stein, U. Ruschewitz, Z. Anorg. Allg. Chem. 2009, 635, 914-919.

[16] H. Li, M. Eddaoudi, M. O’Keeffe, O. M. Yaghi, Nature 1999, 402, 276.

[17] T. Loiseau, C. Serre, C. Huguenard, G. Fink, F. Taulelle, M. Henry, T. Bataille, G. Férey, Chem. Eur. J. 2004, 10, 1373.

[18] S. S.-Y. Chiu, S. M.-F. Lo, J. P. H. Charmant, A. G. Orpen, I. D. Williams, Science 1999, 283, 1148. 
[19] a) S. Kipp, V. Šepelák, K. D. Becker, Chem. Unserer Zeit 2005, 39, 384-392; b) G. V. Avvakumov, M. Senna, N. V. Kosova, Soft Mechanochemical Synthesis, Springer, Berlin, 2001.

[20] S. M. Hick, C. Griebel, R. G. Blair, Inorg. Chem. 2009, 48, 2333-2338.

[21] R. Kuroda, J. Yoshida, A. Nakamura, S.-I. Nishikiori, CrystEngComm 2009, 11, $427-$ 432.

[22] M. B. J. Atkinson, D.-K. Bučar, A. N. Sokolov, T. Friščić, C. N. Robinson, M. Y. Bilal, N. G. Sinada, A. Chevannes, L. R. MacGillivray, Chem. Commun. 2008, 57135715.

[23] A. Pichon, S. L. James, CrystEngComm 2008, 10, 1839-1847.

[24] STOE WinXPOW - version 1.07, STOE \& Cie GmbH, @2000.

[25] P.-E. Werner, L. Eriksson, M. Westdahl, J. Appl. Crystallogr. 1985, 18, 367-370.

[26] A. C. Larson, R. B. V. Dreele, Los Alamos National Laboratory Report 1994, LAUR 86-748.

[27] Crystallographic data (excluding structure factors) for the structures reported in this paper have been deposited with the Cambridge Crystallographic Data Centre as supplementary publication no. CCDC-741331 (CaADC (1)) and CCDC-741332 $\left(\mathrm{Mg}(\mathrm{ADC})\left(\mathrm{H}_{2} \mathrm{O}\right)_{2}(2)\right)$. Copies of the data can be obtained free of charge on application to CCDC, 12 Union Road, Cambridge CB2 1EZ, UK [fax.: (internat.) + 44 1223/336-033; e-mail: deposit@ccdc.cam.ac.uk].

[28] J. W. Visser, J. Appl. Crystallogr. 1969, 2, 89-95.

[29] A. Altomare, R. Caliandro, M. Camalli, C. Cuocci, C. Giacovazzo, A. G. G. Moliterni, R. Rizzi, J. Appl. Crystallogr. 2004, 37, 1025-1028.

[30] C. Robl, S. Hentschel, Z. Anorg. Allg. Chem. 1990, 591, 188-194.

[31] I. Stein, U. Ruschewitz, Z. Anorg. Allg. Chem. 2006, 632, 2098.

[32] I. Stein, U. Ruschewitz, Z. Anorg. Allg. Chem. 2008, 634, 2082. 
Table 1 Details of crystal structural analysis of CaADC (1) and $\mathrm{Mg}(\mathrm{ADC})\left(\mathrm{H}_{2} \mathrm{O}\right)_{2}(\mathbf{2})$.

\begin{tabular}{|c|c|c|}
\hline & $\mathrm{CaADC}(\mathbf{1})$ & $\mathrm{Mg}(\mathrm{ADC})\left(\mathrm{H}_{2} \mathrm{O}\right)_{2}(\mathbf{2})$ \\
\hline Formula & $\mathrm{C} 4 \mathrm{O} 4 \mathrm{Ca}$ & $\mathrm{C} 4 \mathrm{H} 4 \mathrm{O} 6 \mathrm{Mg}$ \\
\hline Diffractometer, $\lambda$ & Stoe STADI P, 154.059 pm & Stoe STADI P; 154.059 pm \\
\hline Refined data range & $10^{\circ} \leq 2 \theta \leq 80^{\circ}$ & $10^{\circ} \leq 2 \theta \leq 70^{\circ}$ \\
\hline Temperature/K & $295(2)$ & $295(2)$ \\
\hline Space group; $Z$ & I4 ${ }_{1} /$ amd (no. 141), 4 & I2/a (no. 15$), 4$ \\
\hline \multirow[t]{6}{*}{ Unit cell } & $\mathrm{a}=687.78(3) \mathrm{pm}$ & $\mathrm{a}=1120.22(6) \mathrm{pm}$ \\
\hline & $\mathrm{b}=\mathrm{a}$ & $\mathrm{b}=721.33(3) \mathrm{pm}$ \\
\hline & $\mathrm{c}=1020.11(4) \mathrm{pm}$ & $\mathrm{c}=761.56(4) \mathrm{pm}$ \\
\hline & $\alpha=90^{\circ}$ & $\alpha=90^{\circ}$ \\
\hline & $\beta=90^{\circ}$ & $\beta=92.667(3)^{\circ}$ \\
\hline & $\gamma=90^{\circ}$ & $\gamma=90^{\circ}$ \\
\hline Volume & $0.48255(5) \mathrm{nm}^{3}$ & $0.61471(6) \mathrm{nm}^{3}$ \\
\hline Density calculated & $2.094 \mathrm{~kg} / \mathrm{dm}^{3}$ & $1.819 \mathrm{~kg} / \mathrm{dm}^{3}$ \\
\hline No. of refined reflections & 46 & 133 \\
\hline No. of refined parameters & 47 (incl. 28 BG parameters) & 51 (incl. 24 BG parameters) \\
\hline $\mathrm{R}_{\mathrm{P}} ; \mathrm{wR}_{\mathrm{P}} ; \mathrm{R}_{\mathrm{Bragg}}$ & $0.0183 ; 0.0271 ; 0.0196$ & $0.0328 ; 0.0460 ; 0.1035$ \\
\hline$\Delta \rho_{\min / \max } / \mathrm{pm}^{-3}$ & $-0.16 \cdot 10^{-6} / 0.24 \cdot 10^{-6}$ & $-0.53 \cdot 10^{-6} / 0.56 \cdot 10^{-6}$ \\
\hline
\end{tabular}


Table 2 Selected interatomic distances (pm) and angles $\left(^{\circ}\right)$ in $\operatorname{CaADC}(\mathbf{1})$ and $\mathrm{Mg}(\mathrm{ADC})\left(\mathrm{H}_{2} \mathrm{O}\right)_{2}(\mathbf{2})$.

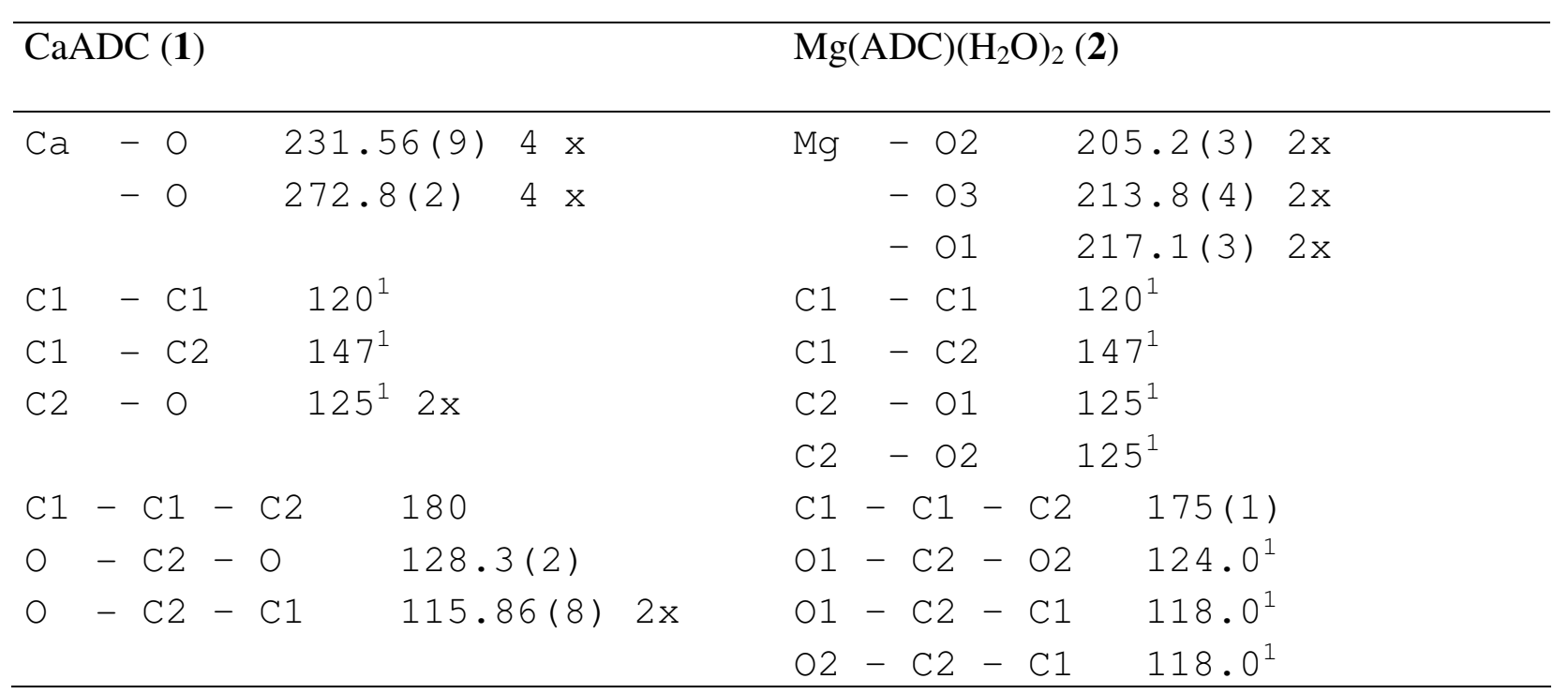

${ }^{1}$ soft constraints 


\section{Figure captions}

Fig. 1 X-ray powder diffraction data of CaADC (black) and $\mathrm{Mg}(\mathrm{ADC})\left(\mathrm{H}_{2} \mathrm{O}\right)_{2}$ (grey), collected on a Stoe STADI P diffractometer $\left(\mathrm{CuK} \alpha_{1}\right.$ radiation).

Fig. 2 CaADC (1): Coordination sphere around Ca showing the atom-numbering scheme.

Fig. 3 CaADC (1): Sketch of the crystal structure emphasizing the diamond-like arrangement of $\mathrm{Ca}^{2+}$ cations; for clarity only two $\mathrm{ADC}^{2-}$ ligands are viewed. $\mathrm{Ca}$ : large dark spheres, $\mathrm{O}$ : small grey spheres, C: small white spheres.

Fig. $4 \mathrm{Mg}(\mathrm{ADC})\left(\mathrm{H}_{2} \mathrm{O}\right)_{2}$ (2): Coordination sphere around $\mathrm{Mg}$ showing the atom-numbering scheme. No hydrogen atoms have been refined for water molecule O3.

Fig. $5 \mathrm{Mg}(\mathrm{ADC})\left(\mathrm{H}_{2} \mathrm{O}\right)_{2}$ (2): Sketch of the crystal structure in a projection along [010]. $\mathrm{Mg}$ : large dark spheres, O: small grey spheres, C: small white spheres.

Fig. 6 CaADC (1): DTA (black) and TG (grey) curves.

Fig. $7 \mathrm{Mg}(\mathrm{ADC})\left(\mathrm{H}_{2} \mathrm{O}\right)_{2}$ (2): DTA (black) and TG (grey) curves. 


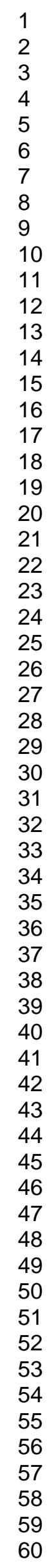

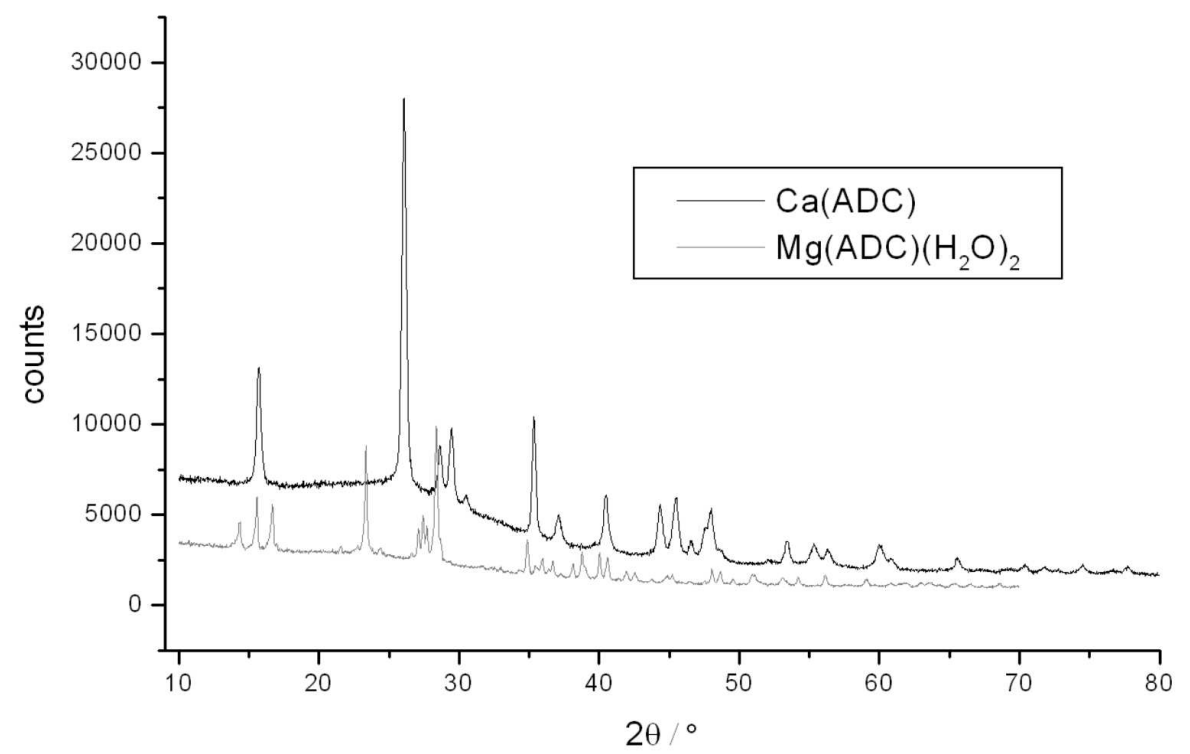




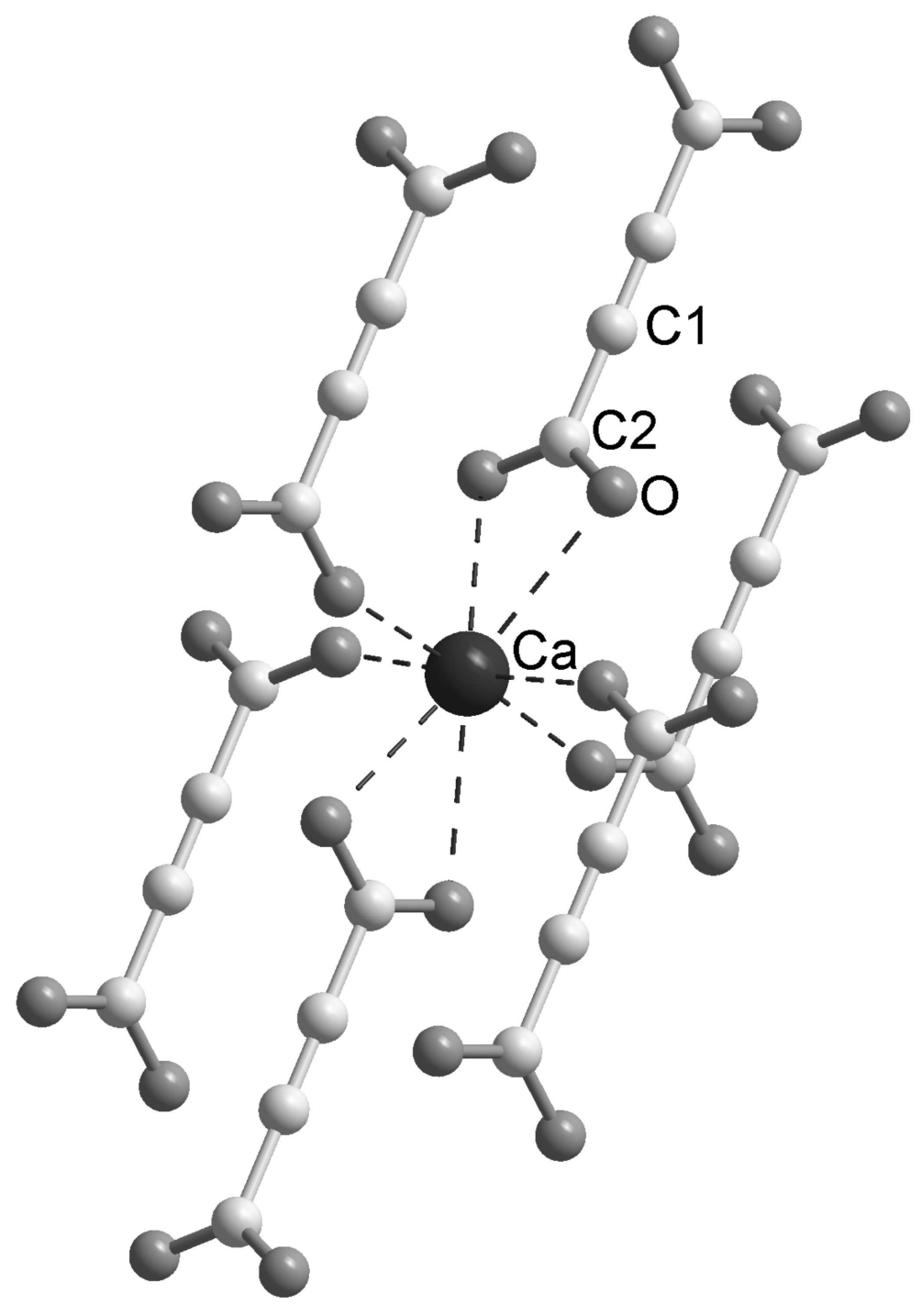

Wiley-VCH 


1
2
3
4
5
6
7
8
9
10
11
12
13
14
15
16
17
18
19
20
21
22
23
24
25
26
27
28
29
30
31
32
33
34
35
36
37
38
39
40
41
42
43
44
45
46
47
48
49
50
50
52
53
55
50

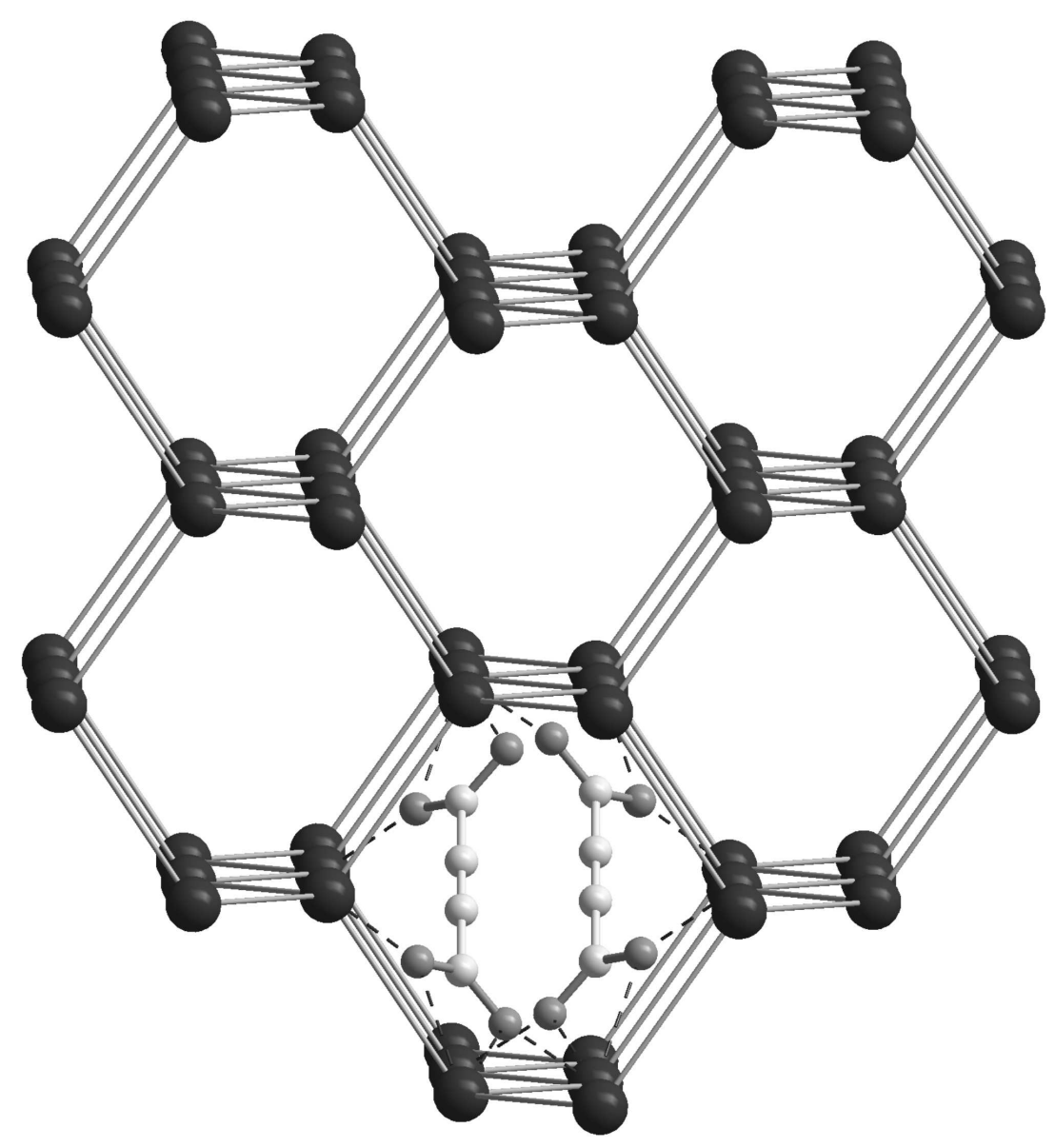

Wiley-VCH 


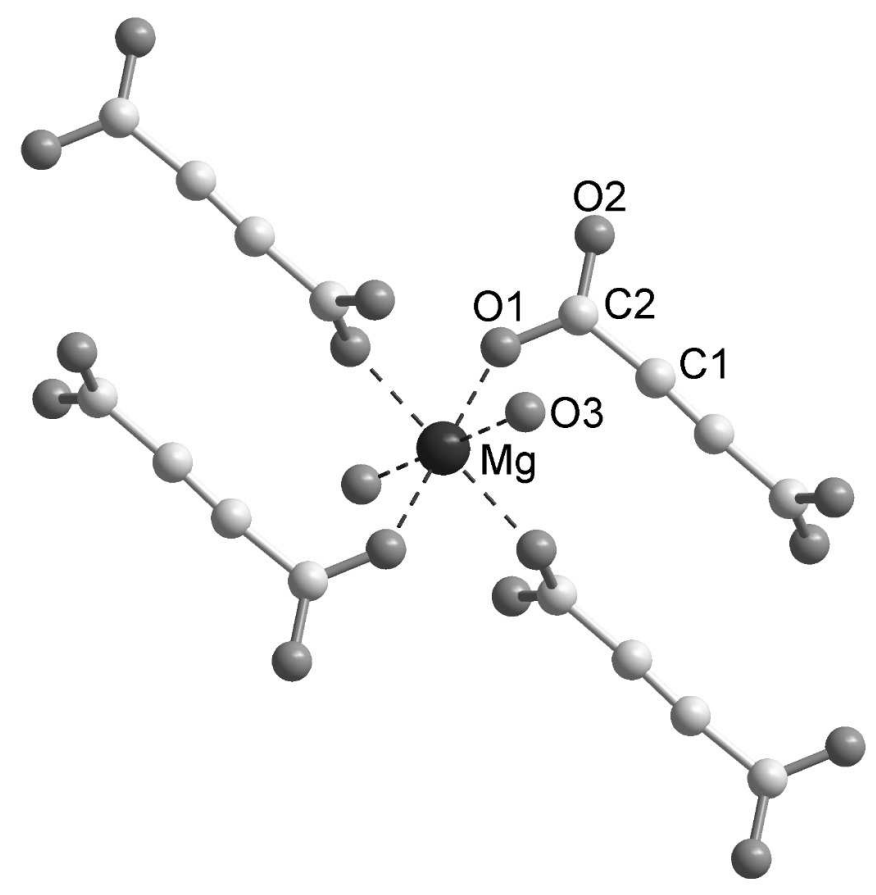

30

32

33

34

35

36

37

38

39

40

41

42

43

44

45

46

47

48

49

50

51

52

53

54

55

56

57

58

59

60

Wiley-VCH 


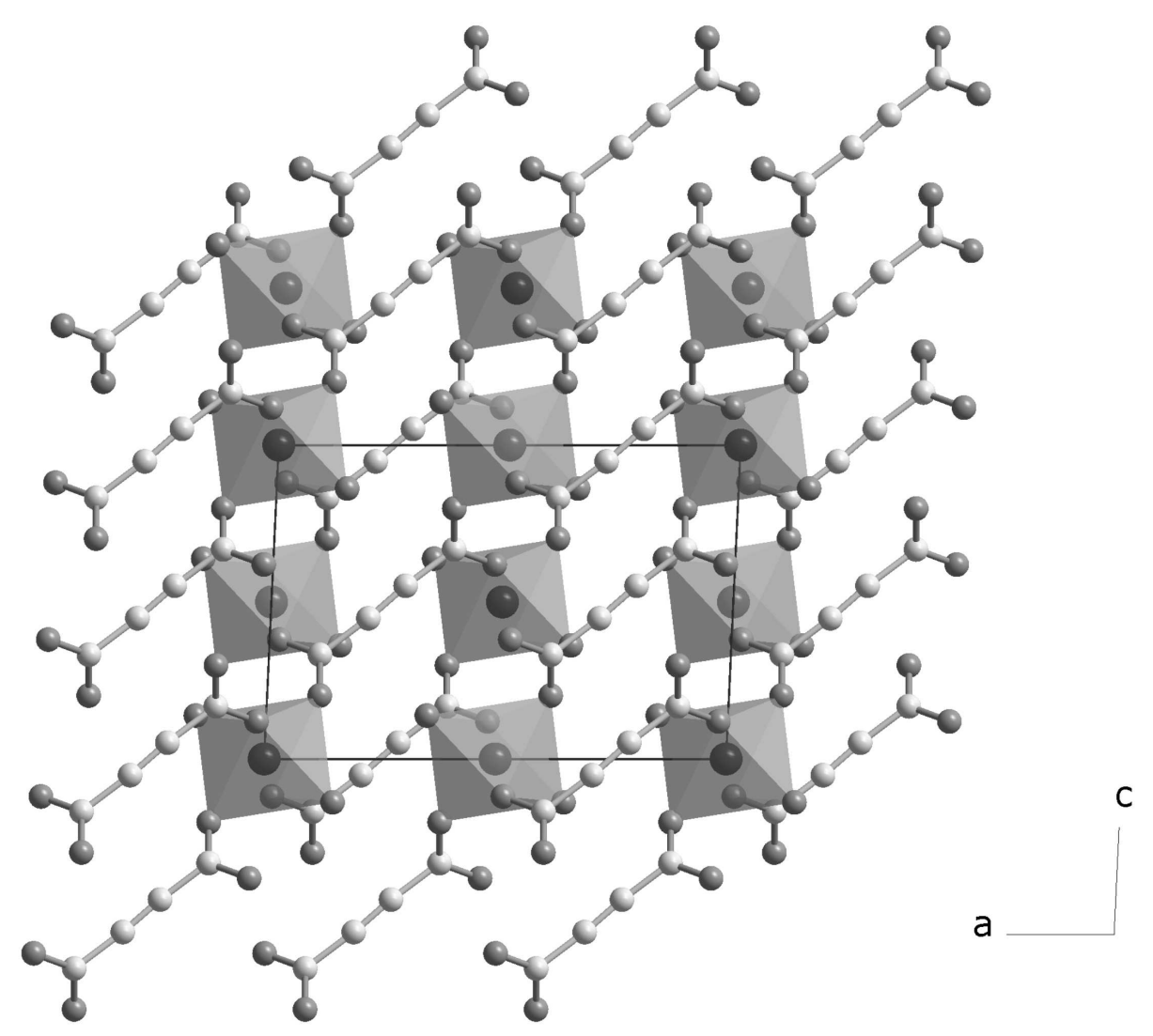

36

37

38

39

40

41

42

43

44

45

46

47

48

49

50

51

52

53

54

55

56

57

58

59

60

Wiley-VCH 


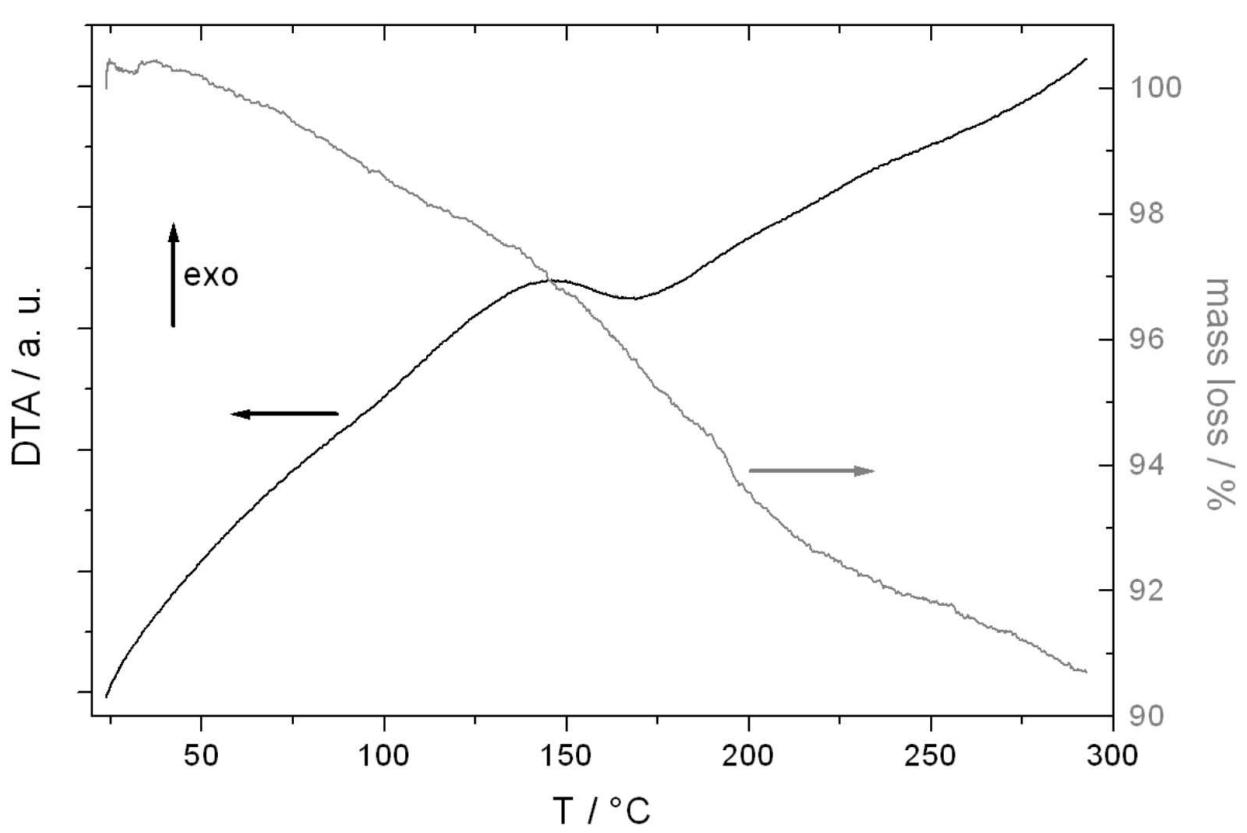

1
2
3
4
5
6
7
8
9
10
11
12
13
14
15
16
17
18
19
20
21
22
23
24
25
26
27
28
29
30
31
32
33
34
35
36
37
38
39
40
41
42
43
44
45
46
47
48
49
50
51
52
53
54
55
56
57
58
60




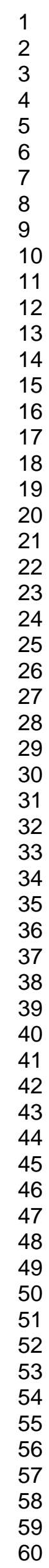

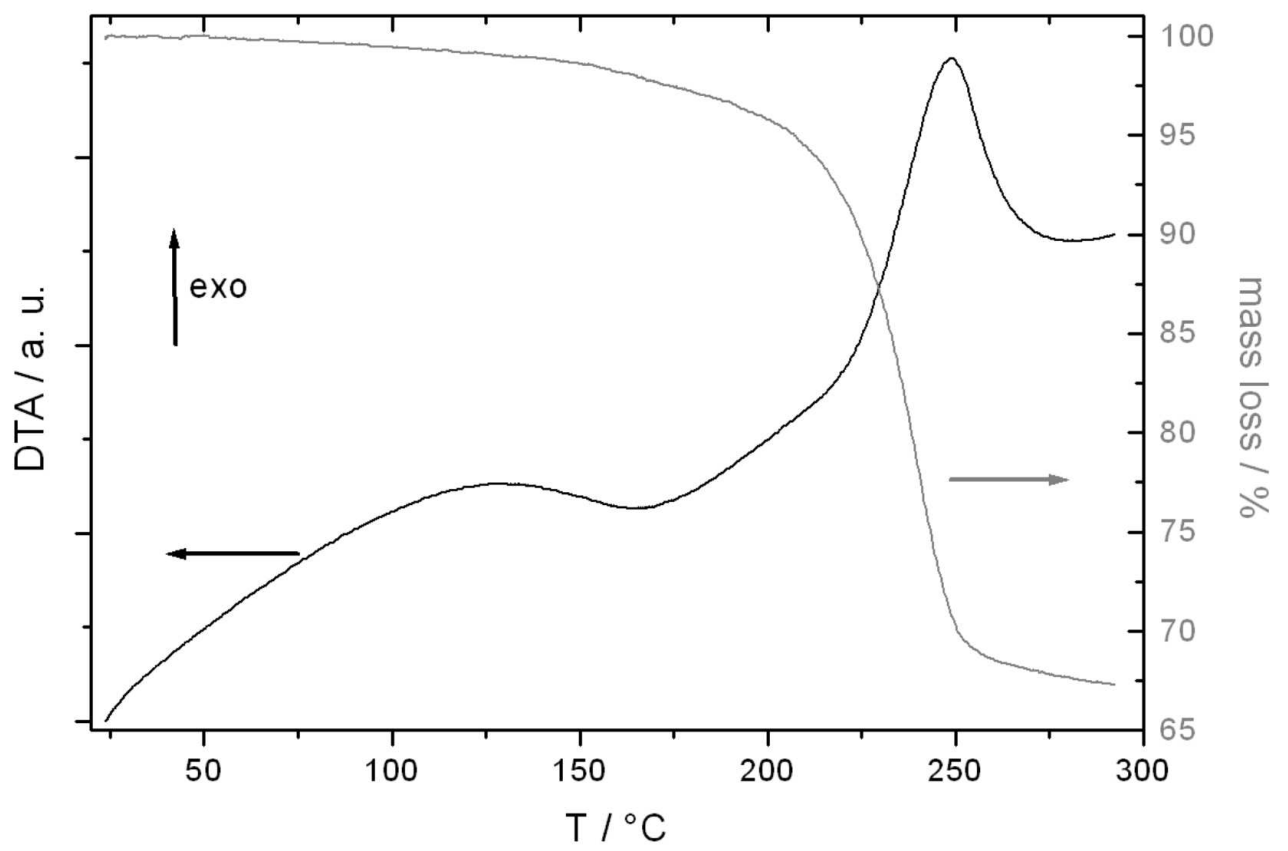

Wiley-VCH 